\title{
PLASMA CELLS IN THE HAMSTER VAGINA: CYCLICAL AND EXPERIMENTAL VARIATIONS
}

\author{
CLARA E. ROIG DE VARGAS-LINARES* \\ Instituto de Histología y Embriologia, Facultad de Ciencias Médicas-U.N.C., \\ Mendoza, Argentina
}

(Received 25th March 1967, revised 18th May 1967)

\begin{abstract}
Summary. The study of the plasma cells in the hamster vagina reveals that a cyclical variation of these cells, parallel to the level of oestrogen in the animal, exists in the mucosa under normal and experimental conditions. At oestrus, the lamina propria shows a small number of plasma cells. At di-oestrus, the plasma cells increase in number and accumulate beneath the epithelium. A few plasma cells are found between the epithelial cells. The concentration of plasma cells and their migration is greater still after castration. Administration of oestrogen to castrated animals provokes a remarkable decrease in the number of plasma cells situated in the lamina propria and their disappearance from the epithelium.

These findings demonstrate that a cyclical variation of plasma cells in the hamster vagina exists which can be regulated by oestrogens. We suggest that these phenomena are related both under normal and experimental conditions to an immunological response situated in the vaginal mucosa.
\end{abstract}

\section{INTRODUCTION}

Nowadays it is a well-known fact that plasma cells are immunologically competent cells, specialized in producing antibody proteins or immunoglobulins (Coons, Leduc \& Connolly, 1955; Nossal, 1959; Miller, 1964). Furthermore, it has been well established that plasma cells represent an important element in the immunological mechanism of the body and that, in response to an antigenic stimulus, they differentiate specifically (Leduc, Coons \& Connolly, 1955).

Plasma cells have been studied in lymphatic organs by means of the electron microscope, under normal conditions (Granboulan, 1960; Moe, 1964; Brooks \& Siegel, 1966) and after antigenic stimulations (Movat \& Wilson, 1959; Thiéry, 1962) but, as far as we know, there are no existing references to the presence of cyclical or experimental variations of plasma cells in the female reproductive tract. As plasma cells are a usual component of the lamina propria \footnotetext{
tina.

* Career Scientific Investigator, Consejo Nacional de Investigaciones Científicas y Técnicas, Argen-
} 
in the hamster vagina during metoestrus (Roig de Vargas-Linares \& Burgos, 1964), we decided to study the behaviour of these cells under normal and experimental conditions. The present paper describes the cyclical variation of plasma cells under physiological conditions and the variations following castration and oestrogen treatment.

\section{MATERIAL AND METHODS}

Adult virgin female golden hamsters, 5 months old and weighing approximately $100 \mathrm{~g}$ each, were maintained under the same environmental and nutritional conditions. The animals were divided into three groups: group I consisted of twenty-four normal hamsters; group II of twelve castrated hamsters, and group III of twelve hamsters castrated and treated with oestrogen. The animals of group I were followed during three cycles with vaginal smears and killed in the following cycle while they were in oestrus or in di-oestrus. The animals in groups II and III were bilaterally ovariectomized under intraperitoneal Nembutal anaesthesia. Those in group II were killed 20,30 or 60 days after castration. The animals in group III received a subcutaneous injection of $0.1 \mathrm{mg}$ of oestradiol in oil 30 days after castration, and were killed 18, 48 or $70 \mathrm{hr}$ later. The vaginae were opened while the animals were under intraperitoneal Nembutal anaesthesia and a Palade's fixative was dropped upon the vaginal surface. The vagina was quickly removed and the upper two-thirds of the mucosa was cut into longitudinal strips $1 \mathrm{~mm}$ thick, and immediately placed in fresh Palade's fixative for $2 \mathrm{hr}$. Some of this material was previously fixed with $10 \%$ acrolein in s-colloidin buffer at $\mathrm{pH} 7 \cdot 4$ for $10 \mathrm{~min}$. The tissue was dehydrated in graded ethanol and embedded in Epon (Luft, 1961). One-micron sections from a Porter-Blum or a Huxley ultramicrotome were stained with toluidine blue-borax and examined with the light microscope for orientation. Adjacent ultra-thin sections were mounted on copper grids and stained with uranyl-acetate and lead-citrate (Reynolds, 1963). Micrographs were obtained with a Siemens Elmiskop I electron microscope at an original magnification from 2500 to 20,000. For light microscopy, some of the vaginae were fixed in Stieve's fluid, dehydrated and embedded in paraffin wax. Sections were cut at $5 \mu$ and stained as follows: (a) with haematoxylin and eosin; (b) methyl-green and pyronin $Y$ (Kurnick, 1955), and (c) with $0.5 \%$ toluidine blue.

\section{RESULTS}

\section{Light microscopy}

Oestrus. The lamina propria contains occasional plasma cells. These cells show a typical basophilic and pyroninophilic cytoplasm with an eccentric nucleus and a clear juxta-nuclear zone. They have never been observed in the epithelium during oestrus (Pl. 1, Fig. 1).

$D i$-oestrus. In the lamina propria plasma cells are more numerous. They were found either isolated or in groups; usually accumulated near the epithelium. Their cytoplasm was then found to be slightly vacuolated and more basophilic and pyroninophilic (Pl. 1, Fig. 2). Some of the plasma cells were found among the epithelial cells. 
Castrated animals. There was a remarkable increase in the number of plasma cells in the lamina propria. Their size and shape appeared different and they tended to form groups close to the epithelium. Their cytoplasm seemed slightly larger in volume and more vacuolated than during di-oestrus (Pl. 2, Fig. 3). They were frequently accompanied by lymphocytes and mast cells and were sometimes found among the epithelial cells (Pl. 2, Fig. 4).

Castrated and oestrogen-treated animals. Forty-eight hours after the oestrogen injection the plasma cells situated in the lamina propria diminished in number and volume. A few migrating cells of the plasmacytic or lymphocytic type were seen in the epithelium (Pl. 2, Fig. 5). Seventy hours after the oestrogen injection the plasma cells disappeared from the epithelium, though they persisted in the lamina propria in a reduced number.

\section{Electron microscopy}

In castrated hamsters the lamina propria showed accumulations of typical plasma cells beneath the epithelium. These clusters of plasma cells were more numerous in all the castrated animals than in the di-oestrous ones. The cytoplasm of the plasma cells, both under normal and experimental conditions, showed a well-developed endoplasmic reticulum, the lumen of the cisternae containing a fine granulated material (Pl. 3, Fig. 6) and occasional dense and spherical intracisternal granules (Pl. 5, Fig. 8). The Golgi complex occupied a juxta-nuclear zone (Pl. 3, Fig. 6). Oval and round shaped mitochondria with regular cristae (Pl. 3, Fig. 6 and Pl. 6, Fig. 9) were observed in other parts of the cytoplasm. The characteristic nucleus of the plasma cell contained large chromatin masses at the periphery, pores in the envelope (Pl. 3, Fig. 6, arrows) and a well developed perinuclear space (Pl. 3, Fig. 6). Commonly, lymphocytes were seen in the intercellular spaces of the epithelium, dilating it considerably (Pl. 4, Fig. 7 and Pl. 5, Fig. 8). In the areas in contact with the adjacent epithelial cells, the plasma cells showed irregular projections which appear to interdigitate with the processes present on the surface of the epithelial cells (Pl. 6, Fig. 9). Pinocytotic activity, represented by vesicles and concavities was present on the surface of both. Some of these concavities contained a moderately electron-dense material (Pl. 5, Figs. 8a, 8b and Pl. 6, Fig. 9). Eighteen hours after the oestrogen treatment of castrated animals, the plasma cell within the intercellular space showed a striking change: the superficial projections described above had disappeared and the cell contours appeared smooth and regular; the intercellular space was narrow and uniform in width. The outline of the adjacent epithelial cells was also smooth and parallel to that of the plasma cell (Pl. 6, Fig. 10). Bundles of filaments were seen in the cytoplasm of the epithelial cells (Pl. 6, Fig. 10).

\section{DISCUSSION}

It had already been observed, in a previous report (Roig de Vargas-Linares \& Burgos, 1964), that during metoestrus the plasma cells are normally present in the lamina propria of the hamster's vaginal mucosa. During the present work we observed that the presence of plasma cells in the lamina propria and the 
migration of these cells to the vaginal lumen occurred during di-oestrus, and that both phenomena were intensified by castration. Plasma cells are known to synthesize immunoglobulins, the globulins with antibody capacity (Ham, 1965), and to be one of the chief mediators in immunological responses (Nossal \& Makëla, 1962). The accumulation of plasma cells in the lamina propria of the intestinal mucosa, observed in rodents (Deane, 1963, 1964) and in human beings (Donnellan, 1965), was related to the role played by plasma cells in the defensive mechanisms of the body. Based on these observations, we assumed that plasma cell variations, which occur in both normal and experimental conditions, are the morphological expression of an immunological response located in the vaginal mucosa. As far as we know, our observations constitute the first demonstration of a cycle of plasma cells beneath the vaginal epithelium and their migration to the vaginal lumen. It seems reasonable to postulate that

\section{EXPLANATION OF PLATES 1-6}

Figs. 1 to 5 are light micrographs of the vaginal mucosa of the hamster stained with $0.5 \%$ toluidine blue. Figs. 6 to 9 are electron micrographs of the vaginal mucosa of castrated hamsters, stained with lead-uranyl. Fig. 10 is an electron micrograph of the vaginal mucosa of a castrated and oestrogen-treated hamster, stained with lead-uranyl.

FIG. 1. Oestrus, showing a plasma cell (PC) in the lamina propria (LP), cornified stratified epithelium (EP), and mucified cells $(M)$ in the vaginal lumen $(L) . \times 650$.

FIG. 2. Di-oestrus. Several plasma cells (PC), are present in the lamina propria (LP) near the epithelium (Ep). Lymphocyte (Li). Blood vessel $(v)$. Vaginal lumen $(\mathrm{L}) . \times 650$.

FIG. 3. Castrated hamster. Numerous plasma cells (PC) of different size and shape, and showing an intense basophilic cytoplasm. Lamina propria (LP). Mast cell (MC). Vaginal lumen $(\mathrm{L}) . \times 650$.

FIG. 4. Castrated hamster. Plasma cell (PC) in the lamina propria (LP) and in the thin epithelium (Ep). Mast cells (MC). Vaginal lumen (L). $\times 650$.

Fig. 5. Castrated hamster, $48 \mathrm{hr}$ after the oestrogen injection. A few plasma cells (PC) are found in the lamina propria (LP). Arrows mark migrating cells in the cornified stratified epithelium (EP). Vaginal lumen (L). $\times 650$.

Fig. 6. A cluster of plasma cells in the lamina propria (LP). The endoplasmic reticulum (ER) shows their cisternae with different stages of dilatation and their lumen occupied by a moderately electron-dense material. Golgi complex (G). Mitochondria (M). Nucleus (N). Arrows mark pores in the nuclear envelope. Collagen fibres $(\mathrm{CF}) . \times 10,000$.

FIG. 7. A portion of a plasma cell (PC) occupying an intercellular space (Is) in the vaginal epithelium (EP). Nucleus (N). Mitochondria (M). Lysosome (Li). Desmosome (D). Vaginal lumen (L). $\times 70,000$.

FIG. 8. Another portion of a plasma cell (PC) within an intercellular space (Is). Arrows show dense bodies in the cisternae of the endoplasmic reticulum (ER). Mitochondria (M). Vaginal epithelium (EP). Desmosome (D). $\times 20,000$.

Inset (a). Higher magnification of the area outlined in ' $a$ ', showing projections on the plasma cell surface (PC), and different stages of pinocytotic activity. Epithelial cell (Ep). $\times 50,000$.

Inset (b). Higher magnification of the area outlined in ' $b$ ', showing a concavity in the epithelial cell (Ep), containing a moderately electron dense material. Plasma cell (PC). $\times 50,000$.

FIG. 9. Plasma cell (PC) and adjacent epithelial cells (Ep) showing projections on their surfaces. Arrow marks an invagination of the epithelial cell membrane, containing a moderately electron-dense material. Mitochondria (M). Ribosomes (R). Intercellular space (Is). $\times 80,000$.

Fig. 10. Vaginal epithelium of castrated hamster, killed $18 \mathrm{hr}$ after the oestrogen injection. A plasma cell (PC) within an intercellular space (Is) appears in close relation with adjacent epithelial cells (EP). Note the smooth membranes on both the plasma cell and the epithelial cells. Mitochondria (M). Desmosome (D). Filaments (F). $\times 10,000$. 


\section{PLATE 1}

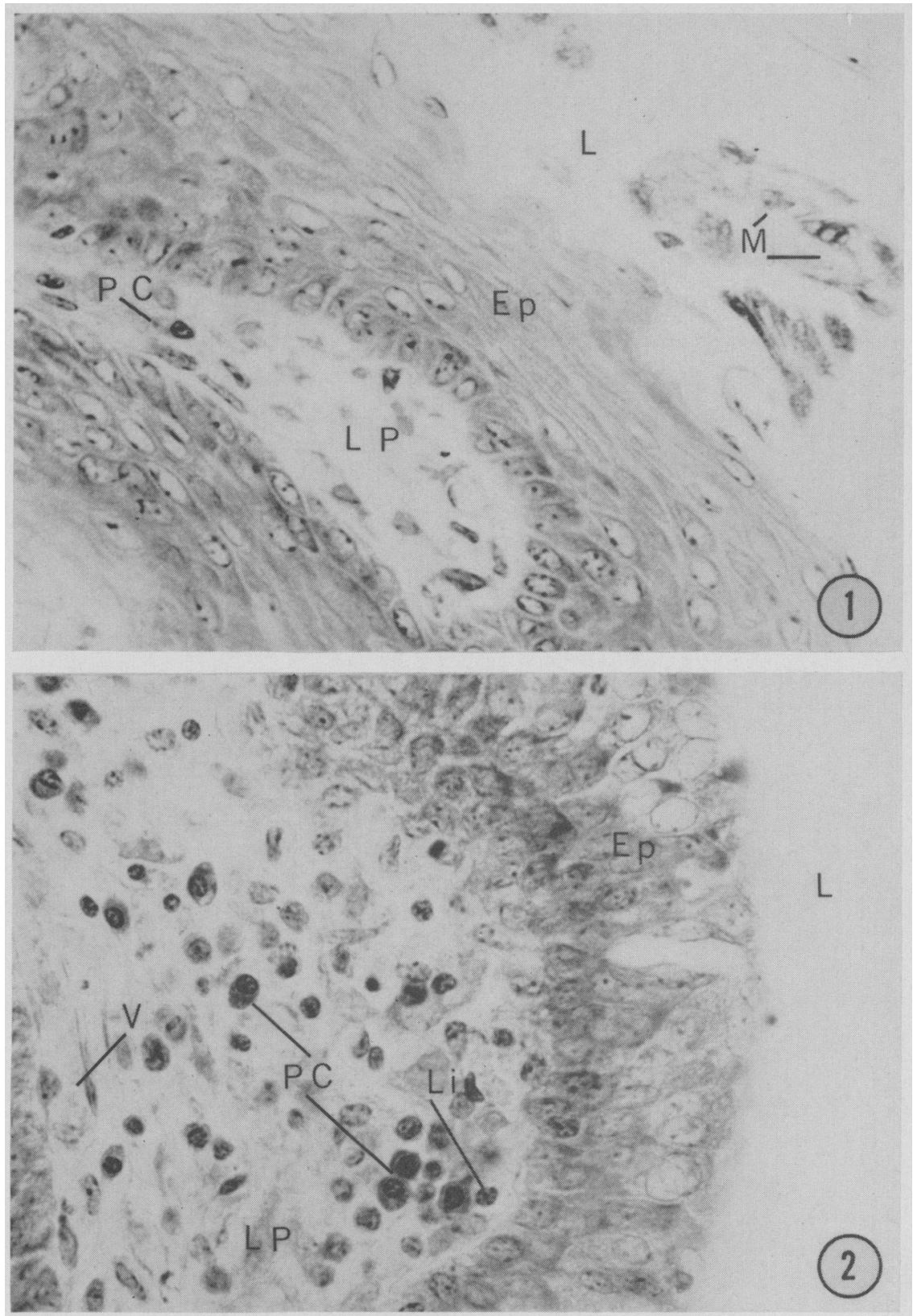

(Facing p. 392) 


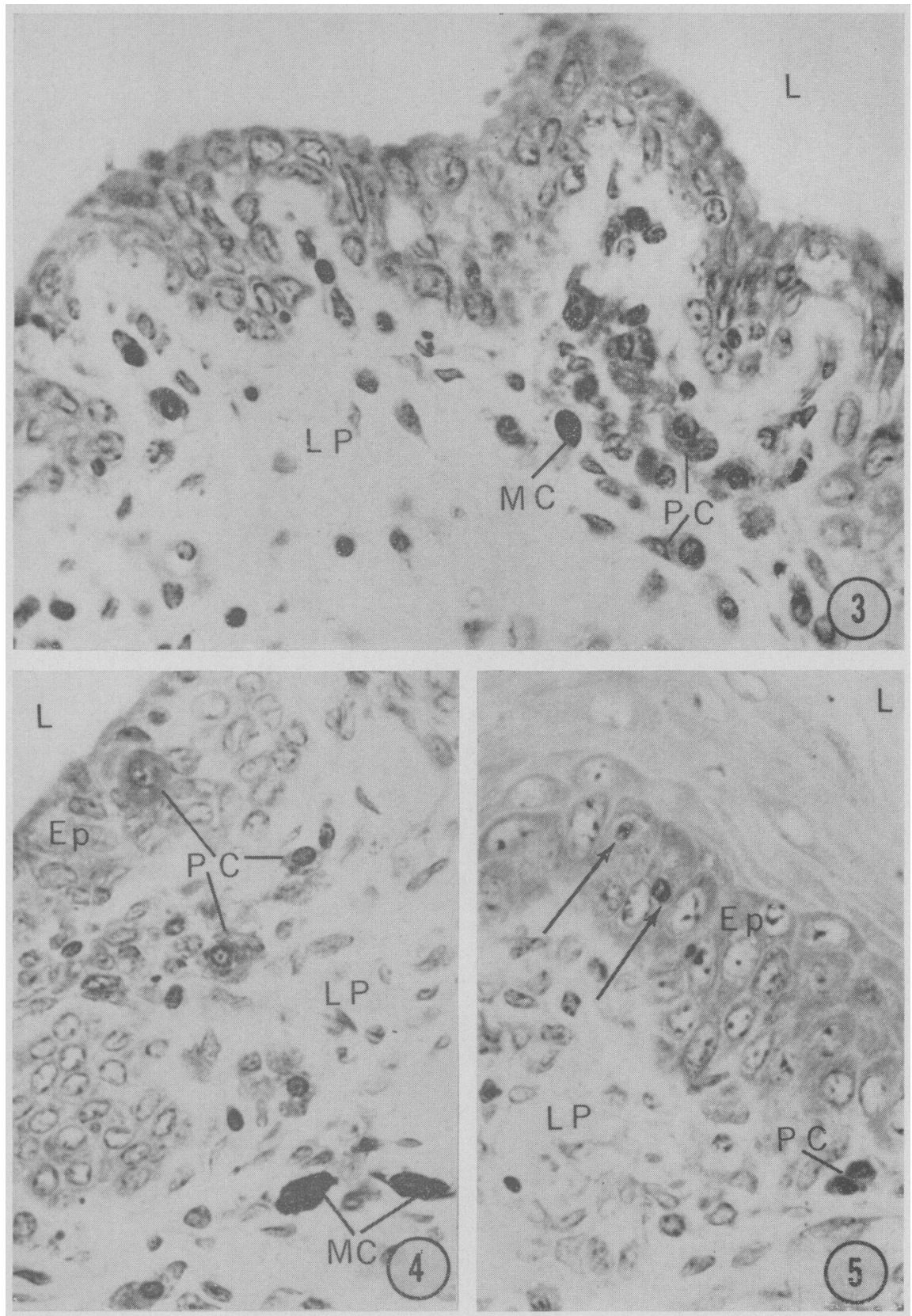


P'LI'E:3

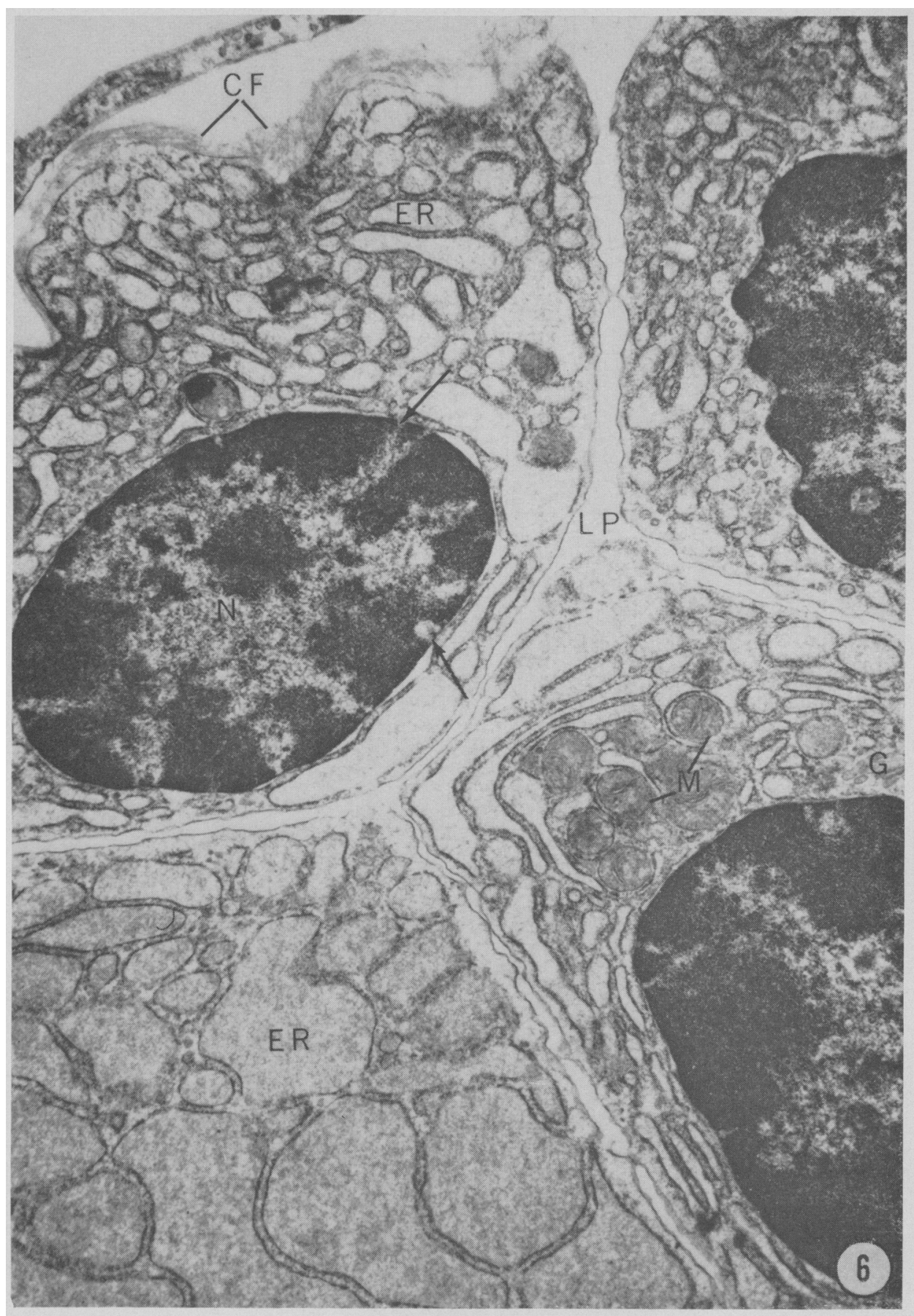




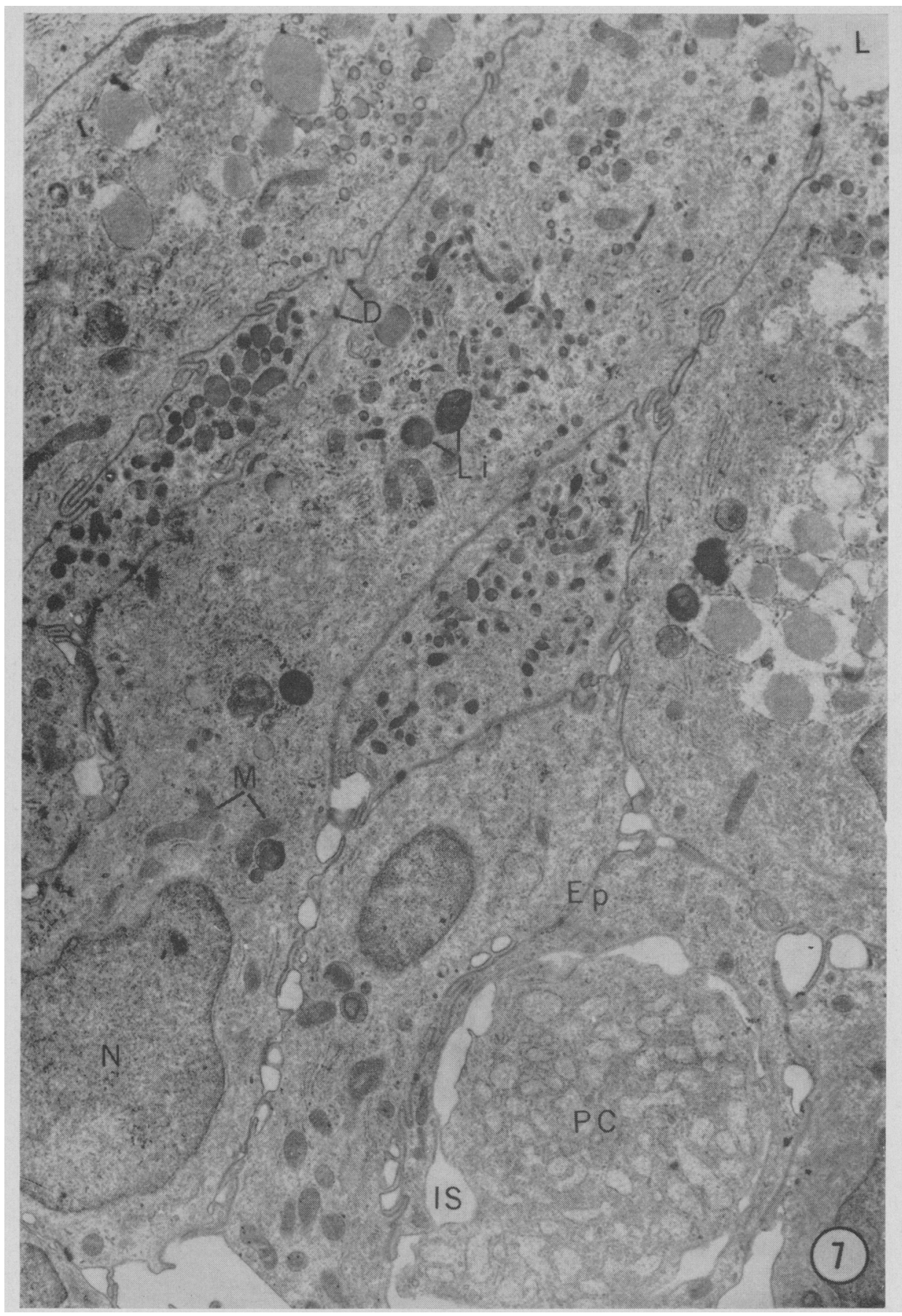


PLATE ;
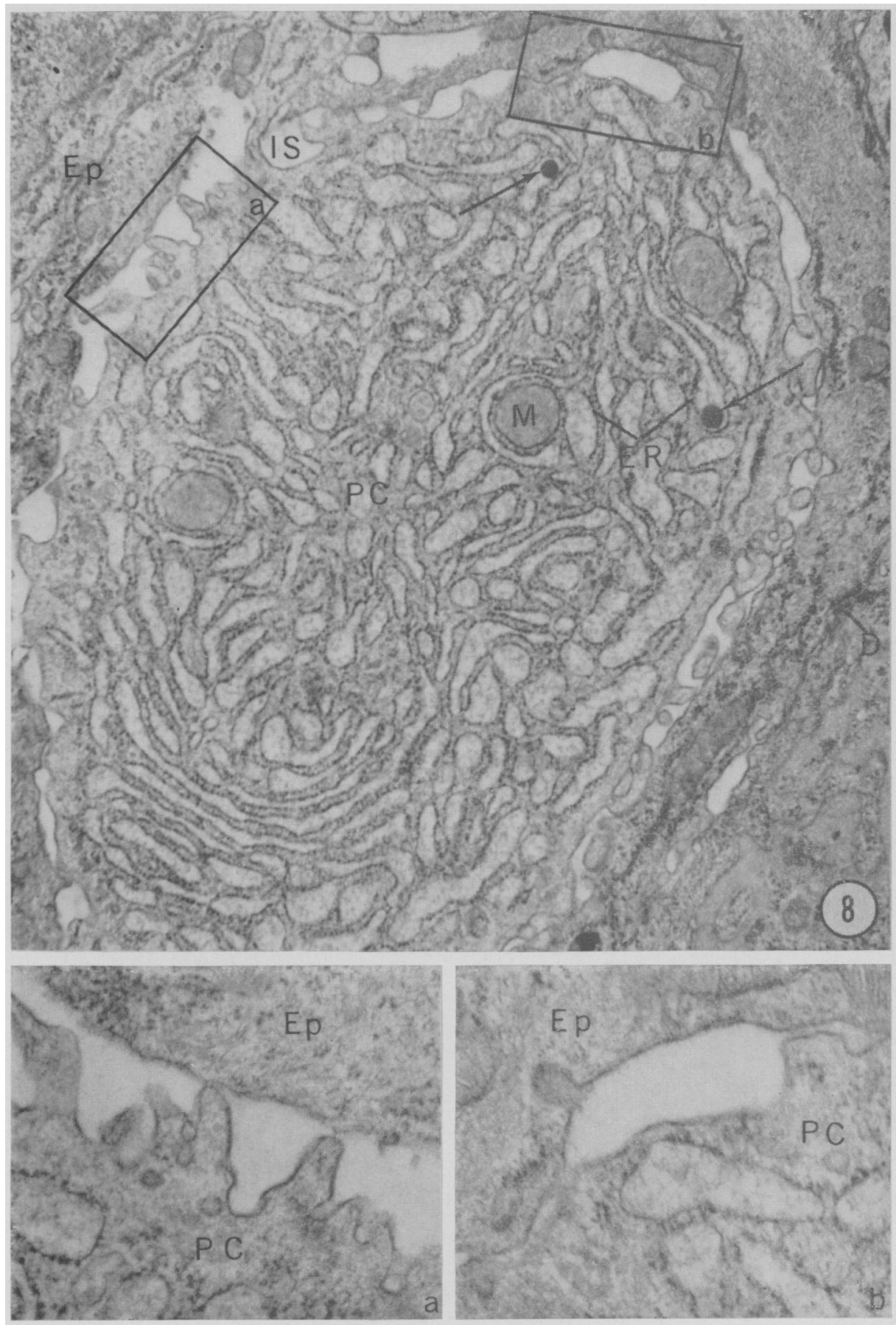


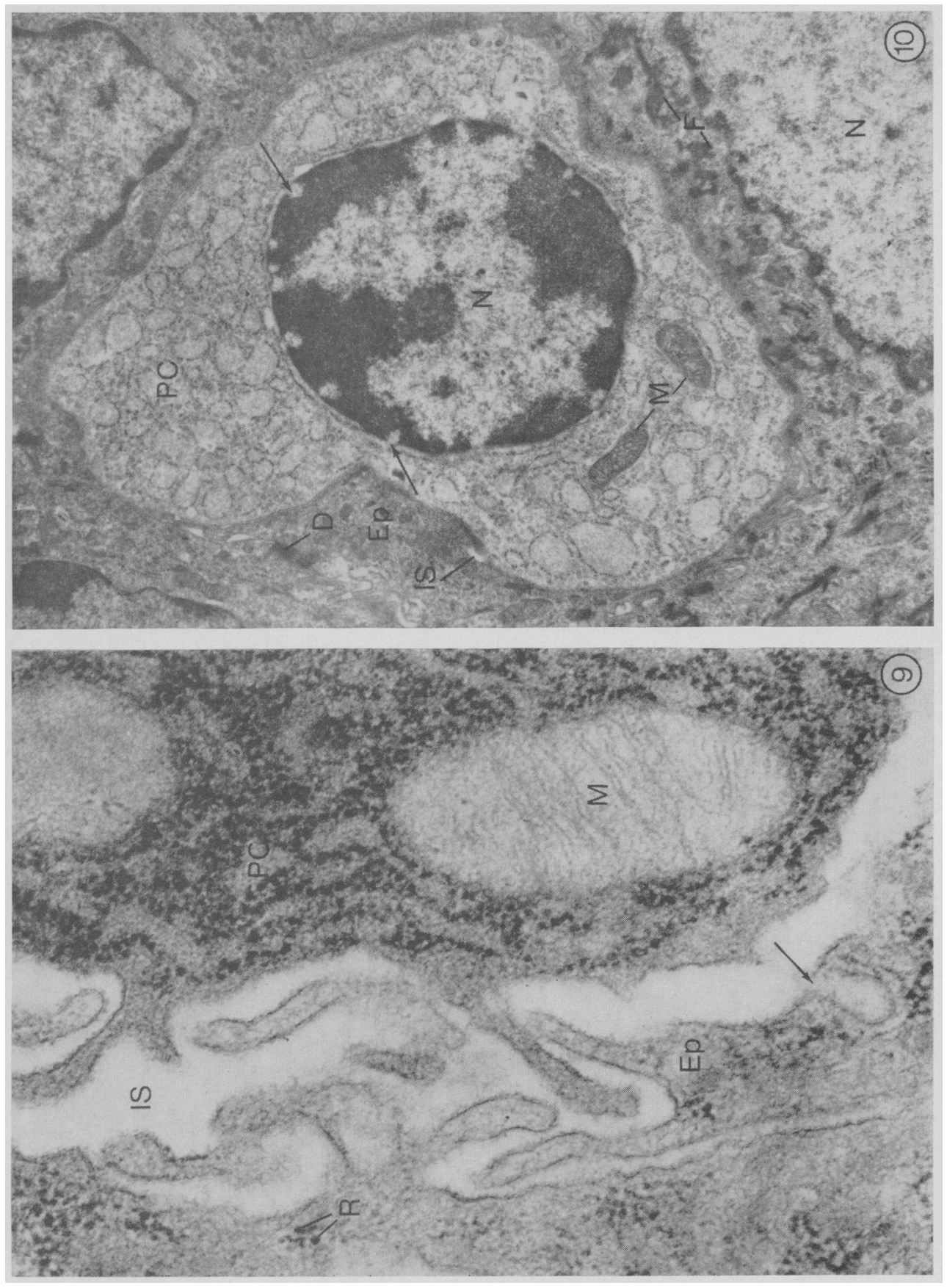

(Facing p. 393) 
this cytological response, which is correlated with the level of oestrogen, involves an immunological mechanism controlled by oestrogens. Assuming that the concentration of plasma cells represents an immunological response, we can make two suggestions about their presence in vaginal tissues: (a) plasma cells are produced in extravaginal zones and migrate toward the vaginal mucosa. Accordingly, Sainte-Marie \& Coons (1964) thought that in lymphoid tissue, plasma cells migrate from the zone of origin towards the sites in which they liberate their globulins; (b) plasma cells are produced in the vaginal mucosa as a response to local antigenic stimuli which provoke the differentiation of immunologically competent cells into plasma cells. In agreement with this hypothesis, a frequent association of immature plasma cells and macrophages has already been observed in the vaginal lamina propria (Roig de Vargas-Linares, unpublished observations). This association has been found to be highly significant in producing antibodies (Thiéry, 1962). Furthermore, evidence of interchange between macrophages and plasma cells has been previously reported by Sorenson (1960) and Thiéry (1962) in lymphoid tissues, and by Deane (1964) and Donnellan (1965) in the intestinal mucosa. According to our observations, the localized concentration of plasma cells was usually followed by their migration through the epithelium towards the vaginal lumen. During this migration, the plasma cells came into intimate contact with the vaginal epithelial cells. We also observed morphological evidences of interchange between plasma cells and epithelial cells, which could well be the structural basis of a transfer of antibodies between plasma cells and epithelial cells.

\section{ACKNOWLEDGMENTS}

This work was supported in part by grants from the Population Council (M-63-121) and The Rockefeller Foundation (RF58028) which are gratefully acknowledged.

The author wishes to express her indebtedness to Dr M. H. Burgos for his encouragement and advice.

\section{REFERENCES}

BRooks, R. E. \& Siegel, B. V. (1966) Normal human lymph node cells: an electron microscopic study. Blood, 27, 687.

Coons, A. H., Leduc, E. H. \& Connolly, J. M. (1955) Leukocytes involved in antibody formation. Ann. N.Y. Acad. Sci. 59, 951.

Deane, H. W. (1963) Apposition of macrophages, plasma cells and eosinophils in lamina propria of gut. F. Cell Biol. 19, 19A.

Deane, H. W. (1964) Some electron microscopic observations on the lamina propria of the gut, with comments on the close association of macrophages, plasma cells and eosinophils. Anat. Rec. 149, 453.

Donnellan, W. L. (1965) The structure of the colonic mucosa. The epithelium and subepithelial reticulohistiocytic complex. Gastroenterology, 49, 496.

Granboulan, N. (1960) Etude au microscope électronique des cellules de la lignée lymphocytaire normale. Revue Hémat. 15, 52.

Ham, A. W. (1965) Histology, 5th edn. Lippincott, Philadelphia.

Kurnick, N. B. (1955) Pyronin Y in the methyl-green pyronin histological stain. Stain Technol. 30, 213.

Leduc, E. H., Coons, A. H. \& Connolly, J. M. (1955) Studies on antibody production. II. The primary and secondary responses in the popliteal lymph node of the rabbit. F. exp. Med. 102, 61 . 
LuFT, J. H. (1961) Improvements in epoxy resin embedding methods. F. biophys. biochem. Cytol. 9, 409.

MilLER, J. J. (1964) An autoradiographic study of plasma cell and lymphocyte survival in rat popliteal lymph nodes. 7. Immun. 92, 673.

MoE, R. E. (1964) Electron microscopic appearance of the parenchyma of lymph nodes. Am. F. Anat. $114,341$.

Movat, H. Z. \& Wilson, D. R. (1959) The fine structure of plasma cells in relation to their function. Can. med. Ass. 7. 81, 154.

Nossal, G. J. V. (1959) Antibody production by single cells. III. The histology of antibody production. Br. J. exp. Path. 40, 301.

Nossal, G. J. V. \& MakËLA, O. (1962) Autoradiographic studies on the immune response. I. The kinetics of the plasma cell proliferation. F. exp. Med. 115, 209.

Reynolds, E. S. (1963) The use of lead citrate at high $\mathrm{pH}$ as an electron-opaque stain in electron microscopy. 7. Cell Biol. 17, 208.

Roig de Vargas-Linares, C. E. \& Burgos, M. H. (1964) Contribution to the study of leucocyte migrations. Q. Fl exp. Physiol. 49, 129.

Sarvte-Marie, G. \& Coons, A. H. (1964) Studies on antibody production. X. Mode of formation of plasmocytes in cell transfer experiments. 7 . exp. Med. 119, 743.

SoRenson, G. D. (1960) An electron microscopic study of popliteal lymph nodes from rabbits. Am. $\mathcal{F}$. Anat. 107, 73.

Thitry, J. P. (1962) Etude au microscope électronique de l'ilot plasmocytaire. F. Microscopie, 1, 275. 